\title{
Genetic risk factors for chronic obstructive pulmonary disease
}

\author{
Monika Tandon*, Sanjeev Tandon**, Mahesh Gupta*, K.B. Gupta**
}

\begin{abstract}
Abstrak
Penyakit paru obstruktif kronik (PPOK) merupakan keadaan patologi kompleks yang dipengaruhi oleh faktor genetik dan lingkungan. Usaha identifikasi faktor-faktor ini sangat penting dalam rangka pengembangan modalitas terapi. Tulisan ini membahas tentang faktor-faktor tersebut dan peranannya dalam pemilihan terapi masa depan. (Med J Indones 2001; 10: 178-81)
\end{abstract}

\begin{abstract}
Chronic obstructive pulmonary disease (COPD) is a complex condition, influenced by environmental and / or genetic risk factors. It is important to identify these factors, and develop new therapies for the management of COPD. This review identifies these factors and highlights the role they will play in future treatment options of COPD. (Med J Indones 2001; 10: 178-81)
\end{abstract}

Keywords: chronic obstructive pulmonary disease, COPD risk factors, genetic of COPD

Chronic obstructive pulmonary disease (COPD) is defined as a disease state characterized by the presence of airflow obstruction due to chronic bronchitis or emphysema; the airflow obstruction is generally progressive, may be accompanied by airway hyperreactivity, and may be partially reversible. ${ }^{\prime}$ COPD has an increasing worldwide prevalence and now ranks fifth in terms of global burden of disease. Treatment is often unsatisfactory and there are no currently available drug treatments that influence the progressive course. There is a widespread therapeutic nihilism, so that many COPD patients are undertreated while others are treated as if they have asthma and this is often inappropriate. It is important to remember that $5-10 \%$ of patients with COPD have never smoked and therefore there are other causal mechanisms apart from cigarette smoking. ${ }^{2}$

\section{RISK FACTORS FOR COPD}

The primary cause of COPD is without question exposure to tobacco smoke. ${ }^{3}$

\footnotetext{
* Department of Pharmacology PT. B.D. Sharma Postgraduate Institute of Medical Sciences Rohtak (Haryana)-124001, India.

** Department of Chest \& TB Sharma Postgraduate Institute of Medical Sciences Rohtak (Haryana)-124001, India.
}

\section{Cigarette smoking}

The major risk factor is cigarette smoking. Smokers have higher death rates for chronic bronchitis and emphysema; they also have a higher prevalence of lung function abnormalities, respiratory symptoms, and all forms of chronic obstructive airway disease. Cigarette smokers also have a greater annual rate of decline in $\mathrm{FEV}_{\mathrm{I}}$. Differences between cigarette smokers and nonsmokers increase in direct proportion to quantity of smoking. Age of starting, total pack years, and current smoking status are predictive of COPD mortality. For unknown reasons, presumably related to constitutional differences or genetic factors only about $10 \%$ of cigarette smokers develop clinically significant COPD.

\section{Passive smoking}

Also known as environmental tabacco smoke (ETS) or second hand smoke, passive smoking is the exposure of nonsmokers to cigarette smoke. Children whose parents smoke have a higher prevalence of respiratory symptoms and respiratory disease and appear to have small but measurable deficiencies in tests of pulmonary function when compared with children of nonsmokers. These deficiencies may presage airway hyperreactivity and the less than maximal attainment of lung function in adult life, although the significance of these findings in relation to future development of COPD is unclear. 


\section{Ambient air pollution}

High levels of urban air pollution are demonstrably harmful to persons with lung disease, but the role of environmental air pollution in the etiology of COPD is unclear; its role appears to be small when compared with that of cigarette smoking. Reported respiratory symptoms, but not lung function deficiencies, have been associated with indoor nitrogen dioxide levels and damp housing. The use of various solid fuels for cooking and heating without adequate ventilation, however result in high levels of indoor air pollution and account for development of COPD.

\section{Bronchial hyperresponsiveness}

Asthma, atopy and nonspecific airway hyperresponsiveness may possibly play a role in COPD. "Asthmatic constitution" - a predisposition to atopic disease, airway hyperresponsiveness and eosinophilia, underlay the development of chronic airflow obstruction; smoking is only extrinsic factor that superimposes on this constitutional susceptibility, leading to chronic airflow obstruction.

\section{Sex, race, and socioeconomic status}

Even controlling for smoking, there is a higher prevalence of respiratory symptoms in men. Mortality rates for COPD are higher in whites than in nonwhites, but the difference is decreasing in males. Morbidity and mortality rates are inversely related to socioeconomic status and are higher in blue collar than white collar workers.

\section{Occupational factors}

Occupational factors give rise to increased prevalence of chronic airflow obstruction, acceleration of $\mathrm{FEV}_{1}$ decline, and higher COPD mortality. Interaction between cigarette smoking and job exposure to hazardous airborne substances results in higher rates of COPD. However smoking effects greatly exceed occupational effects.

\section{Molecular genetics of COPD}

COPD is a complex disease which is still poorly understood at the molecular level. Many inflammatory cells, mediators, and enzymes are involved, but their relative importance is not yet clear. ${ }^{4-5}$ It appears to be a complex interplay between genetic and environmental factors and many different genes will be involved. Genetic factors are likely important in determing which cigarette smokers are at risk of developing airflow obstruction. Furthermore, some patients develop airflow obstruction at an earlier age, again suggesting that genetic factors may determine the progression of COPD.

Smith and Harrison ${ }^{4}$ were the first to suggest the involvement of genetic susceptibility to oxidative stress in the development of COPD. Previous studies on oxidant-antioxidant imbalance in COPD have focused largely on reactive oxygen species or oxidative molecules such as superoxide anion, hydrogen and hydroxyl radical, nitrogen dioxide, and ozone, as offensive agents. Many have also considered the "classic" antioxidant enzymes such as superoxide dismutase, catalase, and glutathione peroxidase, as well as non-enzymes antioxidants such as $\alpha$-tocopherol, $\beta$-carotene, ascorbate, or glutathione. Since epoxide hydrolases catalyse the hydrolysis of epoxides resulted from oxidative metabolism by cytochrome P450, it is conceivable that this important enzyme does play significant roles in preventing the tissue injury caused by cigarette smoke, together with other detoxifying enzymes such as glutathione S-transferases.

Alpha 1- antitrypsin deficiency - A number of genetic factors have been proposed to increase the risk of developing COPD, but only a few have been confirmed to be clinically significant. ${ }^{6}$ The most important is $\alpha_{1}$-antitrypsin deficiency; the odds ratio for the development of COPD in association with the homozygous $\mathrm{ZZ}$ phenotype (presence verses absence) has been calculated at more than 30. As $\alpha_{1}$-antitrypsin is a potent inhibitor of neutrophil elastase, the recognition of this association has led to an elastaseantielastase hypothesis or, more broadly, a proteaseantiprotease hypotheis as a possible explanation for pulmonary emphysema. However, as the frequency of this homozygosity is relatively low, the deficiency acconts for only less than $1 \%$ of all COPD patients. Furthermore, $\alpha_{1}$-antitrypsin deficiency with the PiZZ phenotype is not necessarily associated with COPD and many such people remain healthy in the absence of a smoking history into their sixth and seventh decades. The heterozygous state of $\alpha_{1}$-antitrypsin deficiency has implicated as a possible risk factor for COPD; the odds ratio for developing COPD in MZ heterozygotes (compared with subjects who are neither heterozygotes nor homozygotes) has been reported to range from 1.5 to 5.0. Furthermore, an 
accelerated decline in expiratory flow rates and diffusing capacity, as well as increase in total lung capacity and residual volume, has recently been reported in PiMZ heterozygous subjects in a longitudinal study. In practice, however the PiMZ state has been found to pose a major risk for COPD, especially in the absence of smoking. Indeed, several studies in randomly selected populations have failed to demonstrate a definite association between $\mathrm{MZ}$ phenotype and COPD. ${ }^{\text {? }}$

\section{Mutation of flanking sequence of the antitrypsin} gen - A mutation of the flanking sequence of the $\alpha_{1}$ antitrypsin gene has been associated with COPD in a few studies. The odds ratios for developing COPD (or emphysema) in association with this mutation (present versus absent) were calculated to be 4.3 and 3.2 respectively. This condition is different from $\alpha_{1^{-}}$ antitrypsin in that sequence which codes for protein itself is normal and the basal serum level of $\alpha_{1^{-}}$ antitrypsin is not reduced. It has been suggested that the mutation might diminish the response of $\alpha_{1}$ antitrypsin gene to interleukin 6 and thus suppress the acute phase response of $\alpha_{1}$-antitrypsin. This acute response is thought to counter the increased proteolytic burden at the region of injury induced by inflammation. ${ }^{8}$

$\alpha_{1}$-antichymotrypsin deficiency - The deficiency of another serine protease inhibitor, $\alpha_{1}$-antichymotrypsin, has also been shown to be associated with COPD. This counteracts the adverse enzymic effects of neutrophil cathepsin G, mast cell chymase, and chymotrypsin. However there seems to be wide variation in the prevalence of this deficiency between different populations as is the case for $\alpha_{1}$-antitrypsin deficiency, and this abnormality is unlikely to account for a large proportion of patients who develop COPD.

Tumor necrosis factor- $\alpha$ gene polymorphism - A recent study has reported an association between chronic bronchitis and a polymorphism at 308 position of the tumor necrosis factor $\alpha$ (TNF $\alpha$ ) gene. This polymorphism gives rise to two alleles, TNF 1 and TNF 2. The investigators found that the less common the allele, TNF 2- which was associated with higher basal and induced expression of TNF $\alpha$ was more prevalent in patients with chronic bronchitis. They suggested there was an augumented inflammatory process associated with tissue injury due to increase TNF $\alpha$ expression, and hence the development of chronic bronchitis.

\section{Gene therapy}

The new understanding of the structural basis of $\alpha_{1^{-}}$ antitrypsin deficiency provides a platform for rationale drug design. Any treatment that improves secretion from liver will raise the levels of circulating $\alpha_{1}$-antitrypsin. And so enhance the antiproteinase protection within the lung. The genetic deficiency in the antielastase screen may be rectified biochemically by intravenous infusions of $\alpha_{1}$-antitrypsin. A theoretical option is the intravenous administration of genetically engineered $\alpha_{1}$-antitrypsin with $P_{1}$ methionine mutated to a valine residu." This has little effect on the function of the protein but makes it resistant to oxidation, thereby improving its anti-elastase activity. ${ }^{10}$ Other treatments at an early stage of development include gene therapy and retinoic acid. Vectors carrying the $\alpha_{1}$-antitrypsin gene have been targeted to lung but there is currently insufficient gene expression for this to be a useful therapeutic modality. ${ }^{11}$

\section{CONCLUSION}

There is convincing evidence that genes influence the development of COPD. In a complex polygenic disease such as COPD it is likely that multiple genes are operating and that the influence of each gene in isolation may be relatively weak. The susceptibility to develop COPD with smoking or other environmental factors is likely to depend on the coincidence of several gene polymorphism that act together. COPD has several components including peripheral airway inflammation and parenchymal tissue destruction. There are therefore many possible candidate genes. Using new techniques it is possible to investigate multiple gene polymorphism in parallel and to study their frequency in cigarette smokers who are susceptible to an increased rate of decline in lung function and those who are not. A complimentary approach will be to search for new genes and proteins by mRNA differential display or proteomics. Identification of genetic markers that predict the rate of loss of lung function, or that are associated with responsiveness to different treatments as they are developed may help in disease prevention and improved management of COPD in the future.

\section{REFERENCES}

1. Siafakas NM, Vermeire P, Pride NB. Optimal assessment and management of chronic obstructive pulmonary disease. Eur Respir J 1995; 8:1398-420. 
2. Murray CJL, Lopez A. Evidence based health policy lessons from global burden of disease. Science 1996; 274:70-3.

3. Barnes PJ. New therapies for chronic obstructive pulmonary disease. Thorax 1998; 53:137-47.

4. Smith CAD, Harrison DJ. Association between polymorphism in gene for microsomal epoxide hydrolase and susceptibility to emphysema. Lancet $1997 ; 350: 630-3$.

5. Tarjan E, Magyar P, Vaczi Z. Longitudinal lung function study in heterozygous PiMZ phenotype subjects. Eur Respir J 1994; 7:2199-204.

6. Bruce RM, Cohen BH, Diamond EL. Collaborative study to assess risk of lung disease in PiMZ phenotype subjects. Am Rev Respir Dis 1984; 130: 386-90.
7. Poller W, Meisen C, Olek K. DNA polymorphism of $\alpha_{1}-$ antitrypsin gene region in patients with chronic obstructive pulmonary disease. Eur J Clin Invest 1990; 20:1-7.

8. Nalsheker NA, Morgan K. Regulation of $\alpha_{1}$-antitrypsin gene and a disease-associated mutation in a relad enhance sequence. Am J Respir Crit Care 1994; 150;183-9.

9. Poller W, Faber JP, Scholz S. Mis-sense mutation of $\alpha_{1^{-}}$ antichymotrypsin gene associated with chronic lung disease. Lancet 1992; 339:1538-42.

10. Samilchuk EL, Chuclain AG. Mis- sense mutation of $\alpha_{1-}$ antichymotrypsin gene associated with chronic lung disease. Lancet 1993; 342:624-27.

11. Barnes PJ. Molecular genetics of chronic obstructive pulmonary disease. Thorax $1999 ; 54: 245-52$. 